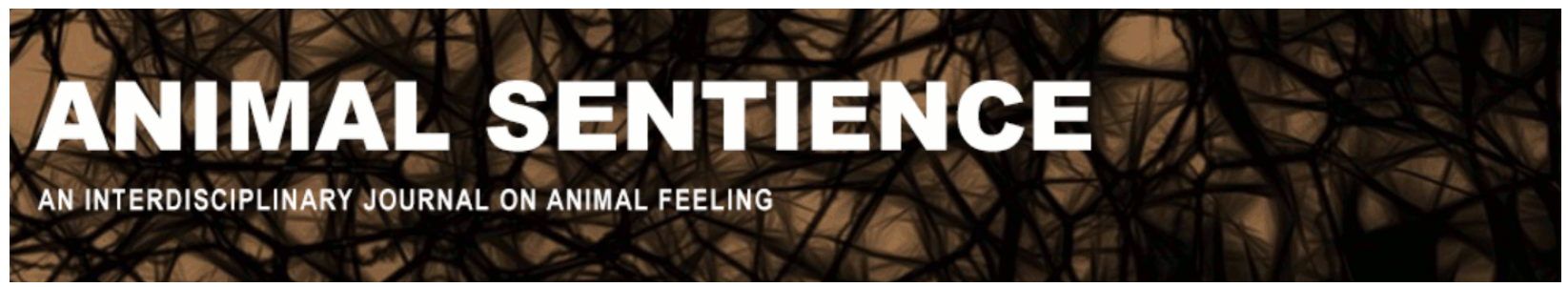

Wadiwel, Dinesh Joseph (2016) Fish and pain: The politics of doubt. Animal Sentience 3(31)

DOI: $10.51291 / 2377-7478.1054$

Date of submission: $2015-10-29$

Date of acceptance: 2015-12-13

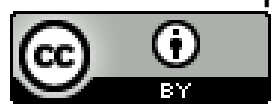

This article has appeared in the journal Animal

Sentience, a peer-reviewed journal on animal

cognition and feeling. It has been made open access,

free for all, by WellBeing International and deposited

in the WBI Studies Repository. For more information,

please contact

wbisr-info@wellbeingintl.org.

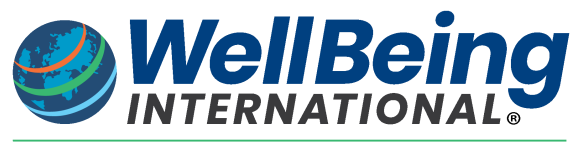

SOLUTIONS FOR PEOPLE, ANIMALS AND ENVIRONMENT 


\title{
Fish and pain: The politics of doubt
}

\author{
Commentary on Key on Fish Pain
}

\author{
Dinesh Wadiwel \\ Department of Sociology and Social Policy \\ University of Sydney
}

\begin{abstract}
The commentaries on Key's (2016) target article make it clear that there is a great deal of doubt about Key's thesis that fish do not feel pain. The political question therefore is about how we should respond to doubt. If the thesis of Key and others (that fish do not feel pain) is wrong, then the negative impact for fish in terms of suffering caused by human utilisation would be extreme. In the face of this doubt, the very least we can do is to adopt basic welfare precautions to mitigate the potential impact if fish do suffer, with attention to the means used to capture, handle and slaughter them.
\end{abstract}

\begin{abstract}
Dinesh Wadiwel dinesh.wadiwel@sydney.edu.au is lecturer in human rights and socio-legal studies at University of Sydney. His research interests include sovereignty and the nature of rights, violence, race and critical animal studies. His current book project explores the relationship between animals and capitalism, building on his monograph, The War against Animals. http://sydney.edu.au/arts/staff/profiles/dinesh.wadiwel.php
\end{abstract}

We face the reminder daily that the suffering of others is fundamentally inaccessible to us. When I visit my dentist and she presses her drill into my tooth, she asks me how this feels. She has administered analgesia, so perhaps the question is superfluous. However, my pain is subjective. My private experience is inaccessible to my dentist; her remedy for this impenetrable difference between my perception and hers is to ask me to describe what I am feeling. If pain in others - its intensity, its specific sensations, its endurability - were accessible to us, then there would be no problem in understanding it: we could perceive it directly, just as we perceive our own pain.

In the face of this uncertainty about the existence or nature of the pain in others, the best we can do is to use indirect methods to try to ascertain their suffering as well as to communicate our own. It is perhaps for this reason that the ethics of how we respond to another being whose phenomenological experience of pain is inaccessible to us has generated philosophical inquiry from a range of different commentators (e.g., Levinas, 1988; Scarry, 1985; Rey, 1998; Dretske, 2006). These are not mere philosophical questions, however, confined to the academy, but also practical problems, with real-world consequences. Human medical practice, for example, has adapted to this philosophical reality concerning pain through the use of subjective self-report techniques (Breivik et al., 2008), including measures for those who cannot speak (Herr, 2011). On the other hand, we know that the worst cases of human violence involve ignoring the pain of others. For example, in her foundational work on pain, Scarry $(1985$, p. 28) points out that torture practices rely upon a systematic refusal to respond to the attempts of the tortured to communicate their pain to their tormentors. 
This essentially solitary experience of pain makes the ethical question of how we respond to it politically fraught, since we must deal not only with the practical question of what resources should be mobilised to respond to known suffering, but also epistemic questions about whether suffering is indeed occurring, how it can be understood and whether it is important enough to respond to. This is why pain in fish is an "ethico-political" question (Rose, 2003, p. 188).

Key (2016) has provided a defence of the view that fish do not feel pain. This sort of view has been put forward by others (Rose, 2014; Rose, 2002) and appears to be aimed, in a somewhat adversarial fashion, at contesting rival work being done to show that fish do indeed suffer and that this has implications for human practices (Sneddon et al., 2003; Sneddon 2003; Braithwaite and Huntingford, 2004; Brown, 2015). Perhaps what is most striking about Key's defence of the view that fish do not feel pain is that despite the evidence presented, there remains so much fundamental doubt over exactly what fish feel. The final paragraph of Key's target article illustrates this doubt perfectly:

\begin{abstract}
"It has been argued here that it is possible to logically and confidently propose the strong inference, based on principles of evolutionary biology and neuroscience, that fish do not feel noxious stimuli. I acknowledge that we do not have the tools at present to definitively 'prove' with a single experimental approach that fish do not feel pain. There are questions in science that are difficult, and simple demonstrations or proof are not available. For example, we can neither re-run the evolution of the animal kingdom nor reconstruct the universe from the big bang in order to provide a simple definitive test of each of these two theses. Given that explaining consciousness is generally considered the hardest problem of neuroscience, it is not surprising that simple demonstrations or proof are not available. What then do noxious stimuli feel like to a fish? The evidence best supports the idea that they don't feel like anything to a fish (Key, 2016)."
\end{abstract}

As a social theorist, I find the argument presented above somewhat perplexing: If we do not have the capacity to verify whether or what fish feel, and if demonstrations or proof are not available, how can we say confidently that noxious stimuli "don't feel like anything to a fish"? It is doubt, rather than confidence, that would seem to prevail. And in many respects, the deep scientific disagreement about how to interpret observed phenomena that might be relevant to fish pain only amplifies this sense of doubt. What do we do when doubt is our starting point?

Key's argument seems to be that until we have certain proof that fish do feel pain, we have no reason to change our current practices in the way we treat fish. This assumes that the rational course of action when there is uncertainty about the potential negative impact of a practice is to continue that practice until something proves it wrong. In some respects this sounds logical: Why should we reduce the speed or alter the course of our ship is sailing at night if we are not reasonably certain that there is an iceberg ahead? But - depending on the odds, and the relative costs of an error of omission versus an error of commission - this can be an imprudent strategy for handling the problem of doubt: We may be better off slowing down at night even while our present monitoring systems are not registering an oncoming iceberg, on the off-chance that they got it wrong. In some cases, we may wish to alter the course of our ship or not even depart on our planned journey. Certainly this would 
be the case if the risks to ourselves or others were very high. It isn't self-evident that continuing full speed until something proves us wrong is the optimal strategy (and certainly not when it is not just the iceberg, but its impact, that is invisible to us).

Let us not pretend, however, that the question of fish pain is just a matter of scientific curiosity or some abstract philosophical dilemma about how to deal with doubt. The real challenge of pain in fish is of course political; and this is precisely why there is a continuing investment in the apparently "rational" view that we cannot alter current fishing practices until we have certain proof that fish suffer. Humans have large-scale material investments in using fish for food and non-food purposes. We have structured production processes in such a way as to almost certainly be inflicting large-scale suffering if fish actually do feel pain. This is why the question of whether fish feel pain has become politically fraught. (Key states this quite plainly, observing that recognition of pain in fish could have "negative implications for native subsistence fishing ... human nutrition and food supply ... and economic development.")

The politics of this situation is perhaps more transparent when we consider the massive scale of human use of fish for food. In 2012, wild fisheries and aquaculture production amounted to 158 million tonnes of fish (UN FAO, 2014, p. 4). World per-capita fish consumption has more or less doubled in the last 50 years, which means that not only are ever more fish being killed each year, but also on average humans are eating more fish per person than ever before (UN FAO, 2014, p. 3). There are few signs that this trend toward increased fish consumption will slow. The growth of fish farming underlines this reality. Annually most fish are caught through wild capture; however, following a recent explosion in the use of aquaculture (UN FAO, 2014, p. 6), farmed fish now account for around $42 \%$ of all fish slaughtered (UN FAO, 2014, p. 19). Recent reports suggest that fish farming has overtaken beef farming globally as a source of food (Marshall, 2013). Making sense of these figures in terms of individual lives is daunting, since official statistics do not offer data on the number of animals killed (that is, the number of individual animals potentially exposed to suffering for human utilisation). A United Kingdom organisation, Fishcount.org.uk, made an estimate in 2010 that between 0.97 and 2.7 trillion wild fish are slaughtered every year through commercial fishing (Mood, 2010; see also Singer, 2010). In a follow-up report in 2012, it was estimated that aquaculture accounted for between 37 and 120 billion fish slaughtered per year (Mood and Brooke, 2012). These figures do not include the potentially large numbers of fish caught globally through recreational fishing practices, though there have been some attempts to quantify the numerical impact of this sort of fishing too (e.g., Smallwood et al., 2011).

The question of whether fish feel pain is also politically fraught because current fishing practices do not conform to the basic welfare practices that are usually applied to landbased animals used for food. Fish are subject to a range of practices that we know would induce severe suffering if applied to other animals who we accept feel pain. This includes mainstay practices in industrialised fishing such as death by asphyxiation (Poli et al., 2005), live cutting practices (Robb, 2008, p. 239; Borderías and Isabel Sánchez-Alonso, 2011), and forms of injury sustained by encounters with fishing gears (e.g., Bartholomew and Bohnsack, 2005; Steina et al., 2012; Ryer, 2002; Lockwood et al., 1993). Recreational fishing practices for example catching a fish using a hook and a line, drawing the animal in, extracting the 
hook and releasing the animal - almost certainly expose fish to injury that would be severely painful if applied to other land-based animals (Cooke and Sneddon, 2007).

In summary, our current mainstay relationship with fish globally is one where we expose trillions of animals annually to injury and death for a range of food and non-food reasons. We apply little or no basic welfare precautions to our use of these animals for our purposes, and we do so in the absence of certainty about whether they experience suffering, even though we know that if fish had a capacity to feel pain, then the level of suffering to which we expose them would be extraordinary. Moreover, we remain resistant to changing mainstay practices to allow for the possibility that fish might suffer - for example, by applying basic welfare precautions - because we perceive the costs (to ourselves) as too high. By any measure, this situation appears to lack justice; it can be rationalized only if one makes the arrogant assumption that humans have some unchallengeable prerogative to prevail over the lives of fish in a completely unfettered way.

My own view is that we need to address our systemic forms of violence against animals, including fish (Wadiwel, 2015; Wadiwel, 2016). This places my own perspective within a broad animal rights tradition, which not only resonates with classic pro-animal scholarship (Singer, 1975; Adams, 1990; Francione, 2007; Regan, 1983), but also emerging scholarship on the political and relational problems of human domination of nonhuman animals (O'Sullivan, 2011; Palmer, 2010; Cochrane, 2012; Donaldson and Kymilicka, 2011).

It is undeniable that a political perspective advocating the end of human the use of fish for food and non-food purposes is esoteric in a world in which our social, economic and political systems remain structured around the use of animals for food, knowledge production and recreation. But we might easily imagine a less radical position on the question of fish and pain.

First, given that we remain in doubt about whether fish feel pain, and given the reality that if fish do feel pain, then our current practices are inflicting an unthinkable amount of suffering upon an equally unthinkable number of living beings, a minimal approach would be to introduce basic welfare precautions to mitigate potential suffering imposed on fish used for food or non-food purposes, with attention to the means used to capture, handle and slaughter them. Until we have confirmation that fish do not suffer, it seems reckless to expose fish to injury that we already know would induce severe suffering if applied in a similar way to the other animals whose capacity to feel pain we already recognize.

Second, it would be reasonable, given the grave implications if fish do suffer, to put an immediate end to any form of fishing purely for pleasure (that is, recreational fishing). Given the doubt over whether fish feel pain, we cannot be confident that recreational fishing practices are not merely an example of pure cruelty for pleasure. As such, these practices appear gratuitous.

My own conviction would be that we ought to do far more than this. However, the practical realities of how we use fish today suggest that even these two "moderate" proposals applying basic welfare for the fish used for food and ending recreational fishing - are already radical in scope and would require massive changes in our relations to fish. But this is 
no reason not to strive toward these minimal goals. Calculating the economic cost of welfare implementation is not an exact science (Hudson, 2010). However, it is not clear that applying basic welfare precautions will have a long-run deleterious impact upon the economics of the industry; arguably, this has not been the case for the application of welfare protection for the land-based animals we use for food (e.g., Vetter, 2014; Menghi et al., 2014, pp. 265-266). Surely, in the face of all the doubt over what fish feel - as evident from the accompanying commentaries - there has to be a rational position other than simply acting as if fish feel nothing?

\section{References}

Adams, C.J. (1990). The Sexual Politics of Meat: A Feminist-Vegetarian Critical Theory. New York: Continuum.

Bartholomew, A. \& Bohnsack, J.A. (2005). A review of catch-and-release angling mortality with implications for no-take reserves. Reviews in Fish Biology and Fisheries, 15, 129154. doi: 10.1007/s11160-005-2175-1

Borderías, A.J. \& Sánchez-Alonso, I. (2011). First processing steps and the quality of wild and farmed fish. Journal of Food Science, 76.1, R1-R5. doi: 10.1111/j.17503841.2010.01900.x

Braithwaite, V.A. \& Huntingford, F.A. (2004). Fish and welfare: Can fish perceive pain and suffering? Animal Welfare, 13, S87-S92.

Breivik, H., Borchgrevink, P.C., Allen, S.M., Rosseland, L.A., Romundstad, L., Breivik Hals, E. K., Kvarstein, G. \& Stubhaug, A. (2008). Assessment of pain. British Journal Anaesthesia, 101.1, 17-24. doi: 10.1093/bja/aen103

Brown, C. (2015). Fish intelligence, sentience and ethics. Animal Cognition, 18.1, 1-17. doi: 10.1007/s10071-014-0761-0

Clifford, H.R. (2002). Trawl stress and escapee vulnerability to predation in juvenile walleye pollock: Is there an unobserved bycatch of behaviorally impaired escapees? Marine Ecology, 232, 269-279. doi: 10.3354/meps232269

Cochrane, A. (2012). Animal Rights Without Liberation. New York: Columbia University Press.

Cooke, S. J., \& Sneddon, L. U. (2007). Animal welfare perspectives on recreational angling. Applied Animal Behaviour Science, 104.3, 176-198. doi: 10.1016/j.applanim.2006.09.002

Donaldson, S., \& Kymlicka, W. (2011). Zoopolis: A Political Theory of Animal Rights. Oxford: Oxford University Press.

Dretske, F. (2006). The epistemology of pain. In M. Aydede (Ed.), Pain: New Essays on its Nature and the Methodology of Its Study (pp. 59-74). Cambridge: MIT Press. 
Francione, G.L. (2007). Animals, Property and the Law. Philadelphia: Temple University Press.

Herr, K., Coyne, P.J., McCaffery, M., Manworren, R. \& Merkel, S. (2011). Pain assessment in the patient unable to self-report: position statement with clinical practice recommendations. Pain Management Nursing, 12.4, 230-250. doi: 10.1016/j.pmn.2011.10.002

Hudson, D. (2010) Discussion: The economics of animal welfare. Journal of Agricultural and Applied Economics. 42.3, 453-455. doi: 10.1017/S1074070800003631

Key, B. (2016). Why fish do not feel pain. Animal Sentience 2016.003.

Levinas, E. (1998). Useless suffering. In Bernasconi R. \& Wood S. (Eds.), The provocation of Levinas: rethinking the Other. New York and London: Routledge.

Lockwood, S.J., Pawson, M.G. \& Eaton, D.R. (1983). The effects of crowding on mackerel (Scomber Scombrus): Physical conditions and mortality. Fisheries Research, 2, 129-147. doi: 10.1016/0165-7836(83)90114-5

Marshall, M. (2013). Farmed fish overtakes farmed beef for first time. New Scientist, 19 June. http://www.newscientist.com/article/dn23719-farmed-fish-overtakes-farmed-beef-forfirst-time.html\#.VLSaUiuUeP8

Menghi, A., de Roest, K., Porcelluzzi, A., Deblitz, C., von Davier, Z., Wildegger, B., de Witte, T., Strohm, K., Garming, H., Dirksmeyer, W., Zimmer, Y., Bölling, D., van Huylenbroek, G. \& Mettepenningen, E. (2014). Assessing farmers' cost of compliance with EU legislation in the fields of environment, animal welfare and food safety. European Commission Directorate-General for Agriculture and Rural Development. http://ec.europa.eu/agriculture/external-studies/2014/farmer-costs/fulltext en.pdf

Mood, A. (2010). Worse Things Happen at Sea: The Welfare of Wild-Caught Fish, Fishcount.org.uk. http://www.fishcount.org.uk/published/standard/fishcountfullrptSR.pdf

Mood, A. and Brooke, P. (2012). Estimating the number of farmed fish killed in global aquaculture each year. http://fishcount.org.uk/published/std/fishcountstudy2.pdf

O’Sullivan, S. (2011). Animals Equality and Democracy. Houndsmills: Palgrave Macmillan.

Palmer, C. (2010). Animal Ethics in Context. Columbia: Columbia University Press.

Poli, B.M., Parisi, G., Scappini, F. \& Zampacavallo, G. (2005). Fish welfare and quality as affected by pre-slaughter and slaughter management. Aquaculture International, 13, 2949. doi: 10.1007/s10499-004-9035-1

Regan, T. (1983). The Case for Animal Rights. Berkley: University of California Press. 
Rey, R. (1995). The history of pain. Cambridge: Harvard University Press.

Robb, D.H.F. (2008). Welfare of fish at harvest. In E.J. Branson (Ed.), Fish Welfare (pp. 217242). Oxford: Blackwell.

Rose, J.D. (2002). The neurobehavioral nature of fishes and the question of awareness and pain. Reviews in Fisheries Science, 10.1, 2002, 1-38. doi: 10.1080/20026491051668

Rose, J.D., Arlinghaus, R., Cooke, S.J., Diggles, D.K., Sawynok, W., Stevens, E.D. \& Wynne, C.D.L. (2014). Can fish really feel pain? Fish and Fisheries, 15.1, 97-133. doi: 10.1111/faf.12010

Rose, N. (2003). Powers of Freedom: Reframing Political Thought. Cambridge: Cambridge University Press.

Scarry, E. (1985). The Body in Pain: The Making and Unmaking of the World. New York: Oxford University Press.

Singer, P. (1975). Animal Liberation. London: Jonathan Cape.

Singer, P. (2010). Fish: The forgotten victims on our plate. The Guardian, 14 September. http://www.theguardian.com/commentisfree/cif-green/2010/sep/14/fish-forgottenvictims

Smallwood, C.B., Pollock, K.H., Wise, B.S., Hall, N.G. \& Gaughan, D.J. (2011). Quantifying recreational fishing catch and effort: a pilot study of shore-based fishers in the Perth Metropolitan area. Fisheries Research Report No. 216, Final NRM Report - Project No. 09040, Department of Fisheries, Western Australia.

Sneddon, L.U. (2003). The evidence for pain in fish: The use of morphine as an analgesic. Applied Animal Behaviour Science, 83.2, 153-162. doi: 10.1016/S0168-1591(03)00113-8

Sneddon, L.U., Braithwaite, V.A. \& Gentle, M.J. (2003). Do fish have nociceptors?: Evidence for the evolution of a vertebrate sensory system. Proceedings of the Royal Society London Series B, 270.1520, 1115-1121. doi: 10.1098/rspb.2003.2349

Steina, J.A., Shultz, A.D., Cooke, S.J., Danylchuk, A.J., Hayward, K. \& Suski, C.D. (2012). The influence of hook size, type, and location on hook retention and survival of angled bonefish (Albula Vulpes). Fisheries Research, 113, 147-152. doi: 10.1016/j.fishres.2011.11.001

UN Food and Agricalture Organization (FAO) (2014) The State of World Fisheries and Aquaculture 2014. http://www.fao.org/3/a-i3720e.pdf

Vetter, S., Vasa, L., Ózsvári, L. (2014). Economic aspects of animal welfare. Acta Polytechnica Hungarica, 11.7, 119-134. doi: 10.12700/APH.11.07.2014.07.8 
Wadiwel, D.J. (2015). The War against Animals. Leiden: Koninklijke Brill.

Wadiwel, D.J. (2016). Do fish resist? Cultural Studies Review, 22.1. (in press). 